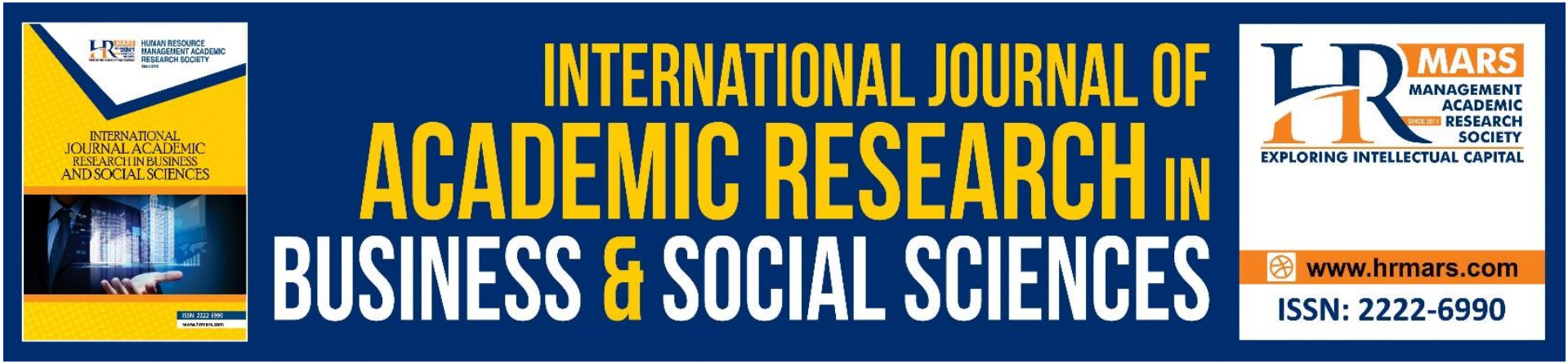

\title{
Understanding Factors of Involvement and Motives of Youth in Volunteerism
}

Siti Anura Rais, Denise Koh Choon Lian, Yasmin Yaccob

To Link this Article: http://dx.doi.org/10.6007/IJARBSS/v11-i12/11752 ～DOI:10.6007/IJARBSS/v11-i12/11752

Received: 12 October 2021, Revised: 13 November 2021, Accepted: 27 November 2021

Published Online: 19 December 2021

In-Text Citation: (Rais et al., 2021)

To Cite this Article: Rais, S. A., Lian, D. K. C., \& Yaccob, Y. (2021). Understanding Factors of Involvement and Motives of Youth in Volunteerism. International Journal of Academic Research in Business and Social Sciences, 11(12), 34-43.

Copyright: (c) 2021 The Author(s)

Published by Human Resource Management Academic Research Society (www.hrmars.com)

This article is published under the Creative Commons Attribution (CC BY 4.0) license. Anyone may reproduce, distribute, translate and create derivative works of this article (for both commercial and non0-commercial purposes), subject to full attribution to the original publication and authors. The full terms of this license may be seen at: http://creativecommons.org/licences/by/4.0/legalcode

Vol. 11, No. 12, 2021, Pg. $34-43$

Full Terms \& Conditions of access and use can be found at http://hrmars.com/index.php/pages/detail/publication-ethics 


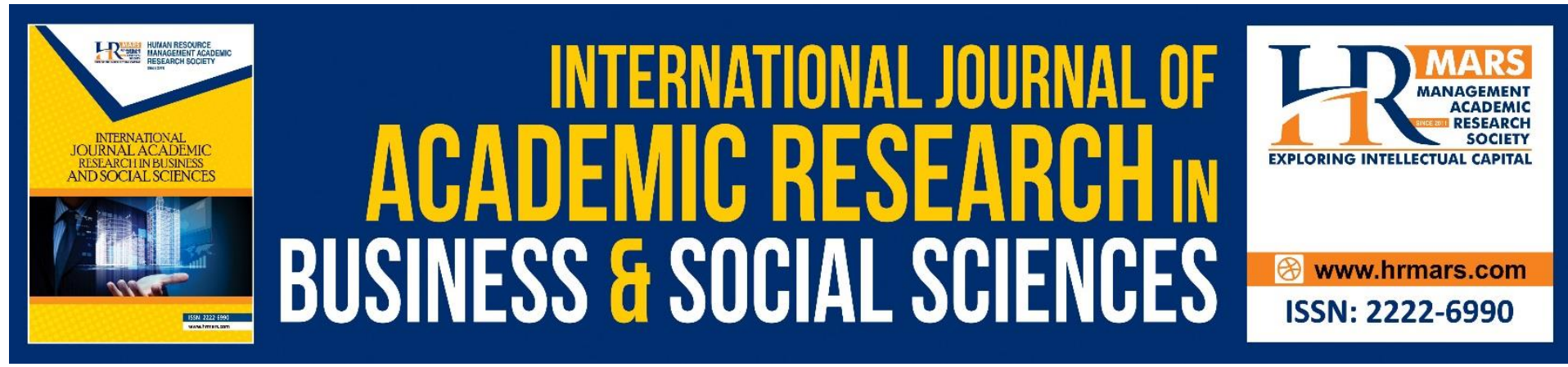

\title{
Understanding Factors of Involvement and Motives of Youth in Volunteerism
}

\author{
Siti Anura Rais ${ }^{1}$, Denise Koh Choon Lian ${ }^{1}$, Yasmin Yaccob² \\ ${ }^{1}$ Faculty of Education, Universiti Kebangsaan Malaysia, ${ }^{2}$ Faculty of Humanities, \\ Management and Science, Universiti Putra Malaysia Bintulu Campus, Sarawak, Malaysia \\ Email correspondence: anurarais@gmail.com
}

\begin{abstract}
Volunteering is a transformative learning activity that involves the contribution of manpower and intellectual support to the community and humanities projects. The objective of the study is to examine the level of involvement and motives for youth participation in volunteer activities. This study uses a quantitative approach with a descriptive design through a questionnaire. A survey was developed using Volunteers Function Inventory (VIF) instrument to assess motivational function towards volunteers. Sampling studies involved 200 respondents aged between 16 to 30 years. The motivational factors of volunteer involvement, namely, value function, understanding function, career function, social function, protection function, and improvement function have been identified as contributing elements to youth involvement in volunteer activities. The findings showed that $76.5 \%$ of youths had volunteered to participate in the volunteering activities. $73.2 \%$ of the respondents had the desire to join volunteering activities again. The study indicated that the highest motive of youth involvement in activities volunteerism is an understanding function $(M=28.12$; $\mathrm{SD}=4.18$ ). Finally, most volunteers had gained and sustain knowledge, skills, and abilities in volunteering activities. This study has important implications for the theoretical, practical, and policy towards the involvement of youth in a volunteering program in Malaysia.
\end{abstract}

Keywords: Involvement, Motivation, Volunteering, Youth

\section{Introduction}

Volunteerism is not a new phenomenon but it is a main resources for performing functions and tasks in an activity, especially youth involvement (Wilson \& Pimm, 1996). It has changed a lot over time as today's society is very dynamic and its structure is improving with newer and forward-looking visions and goals (Ferreira et al., 2012). Volunteering is not a sector that generates income, but it attracts individuals to lend a helping hand. Bussell \& Forbes (2002); Aranda et al (2019) emphasized volunteering activities have their lime and capacity to initiate a change, improve social and private welfare, as well as raising awareness regarding a certain topic or issue. In Malaysia, volunteering involves the surrounding communities which volunteering serves the purpose of helping as well as conserving and offering important services for the community and the country (Hamzah et al., 2016). Volunteering must be done through organizations or social channels that are registered under the Youth 
Organization Registration Office with the objective of welfare activities and social responsibilities. Most registered organizations place the youth as the main leader, shaker, or mover and volunteer. Generally, a volunteer organization is an organization in the third sector whereby it acts as the backbone of a country's development (UN Volunteers, 2016). The members in a volunteering body consist of a huge part of volunteers from various organizations and are managed by workers or full-time working permanent members. The membership of a volunteer organization of course depends on the willingness and ability of the members in fulfilling duties or voluntary work movements. The youth remain an invaluable national asset and drives the country's development, unity and transcendency (Yaccob et al., 2020). Nevertheless, some challenges are often faced by youth volunteers. The challenges include keeping the motivation and spirit alive in every single activity. Studies have shown that the difficulty to push and maintain volunteers is the main challenge. Therefore, youth volunteers especially need to be motivated and encouraged to continuously involve themselves in volunteering activities (Hamzah et al., 2016). Besides, youth participation in volunteering could indirectly prevent youths from engaging in detrimental activities (Moore \& Allen, 1996).

Motivational factor is the important element in pushing the individual to be more actively involved in volunteering activities (Aranda et al., 2019). Motivation is a principal psychological process or a requirement that leads to actions and behaviors. Latham \& Pinder (2005) added that motivation is a product of interactions among individuals and the environment. Studies have shown that motivation in volunteering activities are influenced by other factors including new skills, religious background, environment, and community development, compensation or wage, support system, career development, awareness levels of volunteering activities, and levels of knowledge in a volunteering organization (Smith et al., 2010). These factors are positively and significantly interrelated with volunteering activities (Suanda et al., 2012). According to Clary \& Snyder (1991), the multifactorial model has the main goal through the understanding of reasons, hopes, plans, and goals that characterize the volunteering phenomenon. This model divides motivation according to its function and classifies motivation into six dimensions that are; firstly value that is interpreted as the chance for volunteers to state or acts towards their values, beliefs, knowledge, and ability; secondly comprehension which is the opportunity to gain experience through new learning; thirdly social, which is the possibility of being with friends or gaining new friends; fourthly career which relates to professional career advancements through volunteering works; fifth is protection which offers alternatives to negative emotions; and lastly the sixth is an enhancement which refers to a volunteer's self-worth and ego (Schroeder et al., 2014). Ferreira et al (2012) argue that the multifactorial model is one of the most complete categories in the literature field. This is important in determining the intrinsic and extrinsic motivational existence (Ryan \& Deci, 2000; Raman \& Pashupati, 2002).

Ferreira et al (2012) identified four different motivational categories including developments and learnings; generosity; career recognition and belonging; and protection. Developments and learnings are a part of the motivational category that relates to the learning process, obtaining new perspectives, and expanding experiences. Based on Kemp (2002); Trogdon (2005) volunteers consider their career largely as the source of inspiration to broaden their knowledge and their self-development. Volunteers also believe that this ability can increase 
their understanding levels regarding the public, strengthen their social skills on top of gaining experience (UN Volunteers, 2016).

Meanwhile, Hyde \& Knowles (2013) have identified nine important aspects that motivate youth to participate in volunteering activities; the first being aspiration and the desire to help people or those in need; secondly, to make others happy in a certain period; thirdly, to support the community and environment; fourthly, to join family members in helping those in need; fifthly, to repay the volunteers' good deeds; sixthly, to love the individuals that require help; seventh, to donate necessities for those who need them; eighth, to fill up their free and leisure time; and lastly, as a responsibility towards a volunteering agency or organization.

\section{Methodology}

The population of this study was 420 consisted of youths who attended the National Youth Day Celebration Programme in 2016. According to Krejcie \& Morgan (1970), based on the 95\% confidence interval of $p<0.05$, the sample size deemed suitable was 200 . All the respondents had given a set of self-administered questionnaires and 10 minutes to complete the questionnaire. After the data had complete, the descriptive analysis will determine the frequency and percentage of the respondents' demographic profiles. The motive of the youth's involvement in volunteering activities also had been studied.

Socio-demographic characteristics of the respondents were age, ethnicity, gender, education levels, nationality, and individual monthly income. Motives of participating in volunteering activities were measured using the Volunteer Function Inventory (VFI). The VFI measures six motives which are understanding, values, enhancement, career, social and protective. A seven-point of Likert scale was used to indicate the level of importance for each motive $((1=$ Not at all important, 2 = Low important, 3 = Slightly important, $4=$ Unsure, 5 = Moderately important, 6 = Very important, 7 = Extremely important).

The values function involves opportunities that volunteerism provides for individuals to express values that are very important to the self, related to altruistic and humanitarian concerns for others. The understanding function consists of the opportunity for volunteers to gain and sustain knowledge, skills, and abilities while the social function was volunteering offers opportunities to improve social relationships, it helps individuals to fit in and get along with social groups that are important for them. Career function is to determine participation in voluntary work that increases future job opportunities and protective function showed participation in voluntary work can protect them from negative feelings, it can help the individual to eliminate negative aspects surrounding. Lastly, the enhancement function was by participation in voluntary work the individual can enhance self-esteem, it centers on ego growth and development. The analysis involved the mean value and standard deviation to determine the main motive of youth involvement in volunteering to determine the dispersion of data (Suanda et al., 2012).

\section{Results}

The total number of respondents in this study was 200. Females were the highest participants in this study with a total of 133 (66.5\%) and males contributed 67 (33.5\%). 101 (50.5\%) of the respondents were aged between $21-25$ years old. Most of them were Malays (182 or $91.0 \%$ ). Degree students contributed 104 (52\%) of the respondents and others consisted of 
Master/Doctor Philosophy, Diploma, and below. The family income of the respondents was average RM2001-RM3500 with 49 or $24.5 \%$. Table 1.1 demonstrated the respondent's demographic profile of the study area.

Table 1.1: Respondents' Demographic Profile $(n=200)$

\begin{tabular}{lll}
\hline Demographic Profile & Frequency & Percentage (\%) \\
\hline Gender & & \\
Male & 67 & 33.5 \\
Female & 133 & 66.5 \\
Age & & \\
$16-20$ Years & 59 & 29.5 \\
21-25 Years & 101 & 50.5 \\
26-30 Years & 40 & 20.0 \\
Race & & \\
Malay & 182 & 91.0 \\
Non-Malay & 18 & 9.0 \\
Residence & & \\
Town & 105 & 52.5 \\
Out of Town & 95 & 47.5 \\
Education & & \\
Masters / PhD & 10 & 5.0 \\
Degree & 104 & 52.0 \\
Diploma and below & 86 & 43.0 \\
Occupation Status & & \\
Student & 123 & 61.5 \\
Working & 69 & 34.5 \\
Not Working & 8 & 4.0 \\
Family Income & & \\
RM5000 and above & 30 & 15.0 \\
RM3501-RM5000 & 45 & 22.5 \\
RM2001-RM3500 & 49 & 24.5 \\
RM1001-RM2000 & 46 & 23.0 \\
RM1000 and below & 30 & 15.0 \\
\hline
\end{tabular}

The levels of youth involvement in volunteering are measured through the percentage of participation, period time of involvement, sources, methods of participation in volunteering, and reason for choosing to volunteer. Table 1.2 shows the youth involvement levels in volunteering. The results showed that 153 respondents (76.5\%) were volunteers while 47 respondents (23.5\%) were non -volunteers.

Table 1.2: Youth Involvement Levels in Volunteering

\begin{tabular}{lll}
\hline Youth Involvement & Frequency & Percentage (\%) \\
\hline Yes & 153 & 76.5 \\
No & 47 & 23.5 \\
\hline
\end{tabular}


Table 1.3 below shows that a total of 40 out of 153 respondents $(26.2 \%)$ have been volunteers (less than seven months), 38 respondents ( $24.8 \%$ ) have been volunteers for (3-5 years), while 37 respondents (24.2\%) involved as volunteers in the period (last six years), 28 respondents (18.3\%) in the period (1-2 years) and 10 respondents (6.5\%) in the period (7-11 months). Aranda et al (2019) state that the factor of social motivations increases with age whereas growth and security motivations decrease as volunteers grow older. The evidence suggested that older and younger volunteers might prioritize different motivation, the possible differential effect of age on the relationship between motivation and volunteerism outcomes is not yet sufficiently justified.

Table 1.3: Duration of Involvement in Volunteering Activities

\begin{tabular}{lll}
\hline Duration of Involvement & Frequency & Percentage (\%) \\
6 years recently & 37 & 24.2 \\
3 to 5 years & 38 & 24.8 \\
1 to 2 years & 28 & 18.3 \\
7 to 11 months & 10 & 6.5 \\
Less than 7 months & 40 & 26.2 \\
\hline
\end{tabular}

Next, Table 1.3 shows the duration of which respondents were involved in volunteering. The results showed that $40(26.2 \%)$ respondents had become volunteers in less than seven months. The findings of this study are equivalent to the previous research by Suandi T. (1991) in Rabun et al., (2017). Based on this research, most of the volunteers had a long duration and high level of commitment to volunteering activities. This is probably because there is a high level of volunteerism spirit among youth volunteers. Therefore, they suggest that a high level of commitment should be maintained, and more efforts should be made to improve the behaviour of youth.

Table 1.4: Sources or Methods of Youth Involvement in Volunteering

\begin{tabular}{lll}
\hline Source/ Method & Frequency & Percentage (\%) \\
\hline Friend, family member, colleague, or & 61 & 39.9 \\
other volunteers & & \\
College/ University & 36 & 23.5 \\
Poster or magazine & 18 & 11.8 \\
Employer & 16 & 10.5 \\
organization Website & 10 & 6.5 \\
Volunteer bureau / Similar service & 7 & 4.6 \\
Own decision & 1 & 0.7 \\
Not sure & 4 & 2.5 \\
\hline
\end{tabular}

Table 1.4 shows the sources or methods of youth involvement in volunteering. The findings show that 61 of the respondents (39.9\%) were involved in volunteering activities through family friends, colleagues, or other volunteers, followed by college/university (23.5\%) as the lowest percentage is through their own decision (0.7\%). It shows that the influence of friends is significant in inspiring respondents to participate in volunteering. This finding coincides with the research done by Mamat et al (2018) that found the socials environmental factor such as peers is the primary driver in youth volunteering participation. 
Table 1.5: Motives for volunteering

\begin{tabular}{lcc}
\hline Motives for volunteering & Frequency & Percentage (\%) \\
\hline Heard good things about being a volunteer & 54 & 35.3 \\
To help others & 30 & 19.6 \\
Interested in what the organizer does & 29 & 19.0 \\
Something that can be done & 19 & 12.4 \\
Have family members who are volunteers & 15 & 9.8 \\
Wants to get out of the house & 6 & 3.9 \\
\hline
\end{tabular}

Based on Table 1.5, the main reason for respondents to volunteer is because they always hear good things about being a volunteer (35.3\%), followed by the desire to help others $(19.6 \%)$ and interest in what the organizer implements (19.0\%) whereas the reason of wanting to get out of the house records the lowest percentage (3.9\%). It shows that respondents furnished with positive values. This finding was concurred by Suanda et al (2012); Sadiq (2017) majority of respondents became volunteers because they always hear positive things about volunteers and would like to help those in need. Previous studies related to motivation and volunteerism have also identified the "altruistic" aspect or altruism, i.e., the belief or practice of disinterested and unselfish concern for the well-being of others as the primary motivation (Tapp \& Spanier, 1973; Howarth, 1976; Esmond \& Dunlop, 2004). This concept is still widely discussed (Smith, 1966; Burns et al., 2006; Carpenter \& Myers, 2007).

Researchers have analyzed the youth involvement motives in volunteering using the Volunteer Function Inventory (VFI). The research instruments are developed by Clary \& Snyder (1991) which has been modified according to the suitability of this study. There are six motives contained in VFI, namely protective, values, career, social, understanding, and enhancement as seen in the table below

Table 1.6: Motives of Youth Involvement in Volunteering

\begin{tabular}{lcc}
\hline Motive & Mean & Standard Deviation \\
\hline Understanding & 28.12 & 4.18 \\
Values & 28.08 & 4.36 \\
Enhancement & 27.88 & 4.51 \\
Career & 27.33 & 4.51 \\
Social & 27.03 & 4.42 \\
Protective & 26.95 & 4.59 \\
\hline
\end{tabular}

Table 1.6 shows the mean of the motive of youth involvement in volunteering. The results show that the understanding motive records the highest mean value (mean $=28.12$ ) followed by value motive with the mean value of 28.08 . It shows that the understanding and value of volunteering drive the respondents' participation. The findings portray how respondents gain knowledge, skills, abilities, and human values in every volunteering activity participated.

The findings support past research findings by Muhamad \& Alauddin (2013); Khir et al., (2016) that the value and understanding motives are dominant towards an individual's participation in volunteering. The value factor remains the leading motive for youth to participate voluntarily and show moral values such as empathy, concern, and the desire to help others. 
As for the understanding factor, youth will gain experience and learn new things to apply their knowledge and skills in volunteering.

\section{Conclusion}

Volunteers play a vital role in helping to preserve and provide essential services in the community and country especially Malaysia (Niebuur et al., 2019).Volunteers also assist in unraveling inequality issues and social imbalance along with other problems; hence it is relevant and rational to update information in determining factors that affect the behavior, motivational power, and the need for a volunteer workforce in this country and globally (Kim et al., 2010). This was agreed by Moore \& Allen (1996); Hustinx et al (2010). The obstacles in being a youth volunteer are very challenging, especially to maintain the motivation and volunteering spirit to take part in every single activity carried out every year. Though this problem is an effort to fulfill the mission set by the organization, various research and studies carried out show that the inability to motivate and retain volunteers is an overall challenge (Maund et al., 2020). The findings of the study showed that the respondents got to know about the activity volunteerism through friends, family, colleagues, or other volunteers and through college or university courses. These findings support the findings of the study by Norazrine et al (2017) who found social environmental factors such as peers to be the main driver's youth involvement in volunteer activities.

The involvement of respondents in volunteering shows that this activity gives a positive impact on youth to be more concerned about other people's struggles. Overall, most of the volunteers were happy with volunteering. They feel satisfied with the support, satisfaction and recognition, and organizer information. Meanwhile, the finding is also equivalent to research by Hamzah et al (2016); Aranda et al (2019) that youth have positive involvement motives in volunteering including helping people in need, boosting self-confidence, and adding values to their career.

\section{References}

Aranda, M., Zappalà, S., \& Topa, G. (2019). Motivations for volunteerism, satisfaction, and emotional exhaustion: The moderating effect of volunteers' age. Sustainability (Switzerland), 11(16), 1-16. https://doi.org/10.3390/su11164477

Burns, D. J., Reid, J. S., Toncar, M., Fawcett, J., \& Anderson, C. (2006). Motivations to volunteer: The role of altruism. International Review on Public and Nonprofit Marketing, 3(2), 79-91. https://doi.org/10.1007/bf02893621

Bussell, H., \& Forbes, D. (2002). Understanding the volunteer market: the what, where, who and why of volunteering. International Journal of Nonprofit and Voluntary Sector Marketing, 7(3), 244-257. https://doi.org/10.1002/nvsm.183

Clary, E. G., \& Snyder, M. (1991). A functional analysis of altruism and prosocial behavior. In M. S. Clark (Ed.), Review of Personality and Social Psychology: Vol. 12, Prosocial Behavior (pp. 119-148). Newbury Park, CA: Sage.

Carpenter, J., \& Myers, C. (2007). Why Volunteer? Evidence on the Role of Altruism, Reputation, and Incentives. IZA Discussion Paper, 3021.

Esmond, J., \& Dunlop, P. (2004). Developing Volunteer Motivation Inventory Assess Underlying Motivational Drives. CLAN WA Inc., 82.

Ferreira, M. R., Proença, T., \& Proença, J. F. (2012). Motivations which influence volunteers' satisfaction. In 10th International Conference of the International Society for Third 
Sector Research. 10th International Conference of the International Society for Third Sector Research.

Hamzah, S. R. A., Suandi, T., Shah, J. A., Ismail, I. A., \& Hamzah, A. (2016). Understanding the reasons for Malaysian youth participation in volunteering activities. Athens Journal of Social Sciences, 3(1), 39-51

Howarth, E. (1976). Personality Characteristics of Volunteers. Pychological Reports, 38, 855858.

Hustinx, L., Cnaan, R. A., \& Handy, F. (2010). Navigating Theories of Volunteering: A Hybrid Map for a Complex Phenomenon. Journal for the Theory of Social Behaviour, 40(4), 410434. https://doi.org/10.1111/j.1468-5914.2010.00439.x

Hyde, M. K., \& Knowles, S. R. (2013). What predicts Australian university students' intentions to volunteer their time for community service? Australian Journal of Psychology, 65(3), 135-145. https://doi.org/10.1111/ajpy.12014

Kemp, S. (2002). The Hidden Workforce: Volunteers' Learning in the Olympics. Journal of European Industrial Training, 26: 109-116.

Kim, M., Zhang, J. J., \& Connaughton, D. (2010). Modification of the Volunteer Functions Inventory for application in youth sports. Sport Management Review, 13(1), 25-38. https://doi.org/10.1016/j.smr.2009.04.005

Krejcie, R. V., \& Morgan, D. W. (1970). Determining Sample Size for Research Activities. Educational and Psychological Measurement, 30, 607-610.

Latham, G. P., \& Pinder, C. C. (2005). Work Motivation Theory and Research at the Dawn of the Twenty-First Century. Annu. Rev. Psychol., 56, 485-516.

Mamat, M., Haron, H., Haron, M. S., Universiti, P. C., Jariah, A., Nazri, M., Ismail, N., Chyi, N. Y., Ekonomi, F., Syafiqah, N., Khalid, A., Sains, F., Asrul, M., Ambo, N., \& Pendidikan, F. (2018). Volunteering Among Students of. 9(6), 598-606.

Maund, P. R., Irvine, K. N., Lawson, B., Steadman, J., Risely, K., Cunningham, A. A., \& Davies, Z. G. (2020). What motivates the masses: Understanding why people contribute to conservation citizen science projects. Biological Conservation, 246, 108587. https://doi.org/10.1016/j.biocon.2020.108587

Moore, C. W., \& Allen, J. P. (1996). The effects of volunteering on the young volunteer. Journal of Primary Prevention, 17(2), 231-258. https://doi.org/10.1007/BF02248794

Muhamad, T. A., \& Alauddin, A. N. M. (2013). Motif Penglibatan Sukarelawan Sukan Institusi Pengajian Tinggi terhadap Tahap Kepuasan Diri (Motives for Volunteering in Higher Education Institutions Sports towards Self Satisfaction). Jurnal Pendidikan Malaysia (Malaysian Journal of Education), 38(2), 51-59.

Niebuur, J., Liefbroer, A. C., Steverink, N., \& Smidt, N. (2019). Translation and validation of the volunteer functions inventory (VFI) among the general dutch older population. International Journal of Environmental Research and Public Health, 16(17), 1-14. https://doi.org/10.3390/ijerph16173106

Norazrine, A. T. @ A., Abdul Razaq, A., \& Mahzan, M. A. (2017). Dorongan Persekitaran Sosial dalam Aktiviti Kesukarelawan dalam Kalangan Sukarelawan. Seminar Pendidikan Serantau VIII 2017, 1008-1014.

Rabun, M. N., Hussin, Z. H., \& Ridzuan, M. R. (2017). Exploring university students' level of commitment towards volunteerism. Journal of Administrative Science, 14(1), 1-12

Raman, P., \& Pashupati, K. (2002). Turning Good Citizens into Even Better Ones: The Impact of Program Characteristics and Motivations on Service-Learning Outcomes. Journal of Nonprofit \& Public Sector Marketing, 10 (2): 187-206. 
Ryan R. M., \& Deci E. L. (2000). Self-Determination Theory and the Facilitation of Intrinsic Motivation, Social Development, and Well-Being. American Psychologist, 55 (1): 68-78.

Sadiq, B. (2017). Encourage The Young Ones : Inspiring Students To Volunteer. 1-5.

Schroeder, D. A., Graziano, W. G., Stukas, A. A., Snyder, M., \& Clary, E. G. (2014). Volunteerism and Community Involvement. In The Oxford Handbook of Prosocial Behavior (Issue March). https://doi.org/10.1093/oxfordhb/9780195399813.013.012

Smith, D. H. (1966). Altruism, Volunteers, And Volunterism. Journal of Voluntary Action Research, 1-16.

Smith, K., Holmes, K., Haski-Leventhal, D., Cnaan, R. A., Handy, F., \& Brudney, J. L. (2010). Motivations and Benefits of Student Volunteering: Comparing Regular, Occasional, and Non-Volunteers in Five Countries. Canadian Journal of Nonprofit and Social Economy Research, 1(1), 65-81. https://doi.org/10.22230/cjnser.2010v1n1a2

Suanda, J., Hamzah, M. R., Bahari, A., \& Ku Daud, K. A. (2012). Semangat Kesukarelawan Dalam Kalangan Mahasiswa Melayu di IPTA: Satu Tinjauan ke Arah Pembentukan Pendidikan Kesukarelawanan. Seminar Pendidikan Melayu Antarabangsa (SePMA) 2012, 1-13.

Tapp, J. T., \& Spanier, D. (1973). Personal characteristics of volunteer phone counselors. Journal of Consulting and Clinical Psychology, 41(2), 245-250. https://doi.org/10.1037/h0035137

Trogdon, S. E. I. (2005). A Study of Parks and Recreation Citizen Board Members in North Carolina and Their Motivations for Participation.

UN Volunteers. (2016). The power of volunteerism. https://doi.org/10.1016/j.jacc.2003.11.027

Wilson, A., \& Pimm, G. (1996). The tyranny of the volunteer: The care and feeding of voluntary workforces. Management Decision, 34(4), 24-40. https://doi.org/10.1108/00251749610115134

Yaccob, Y., Ibrani, M., Adam, S., Hidayu, N., \& Jusoh, M. (2020). Level of Social Cohesion of Malaysian Youths As a Community of Practice in a Youth Development Program. EBangi, 17(8), 69-83. 